\title{
Influence of Field Soil Drought Stress on Some Key Physiological, Yield and Quality Traits of Selected Newly-Developed Hexaploid Bread Wheat (Triticum aestivum L.) Cultivars
}

(Pengaruh Tekanan Tanah Kemarau kepada Fisiologi, Hasil dan Sifat Kualiti bagi Kultivar Jenis Roti Gandum Heksaploid Pra-Maju yang Terpilih (Triticum aestivum L.))

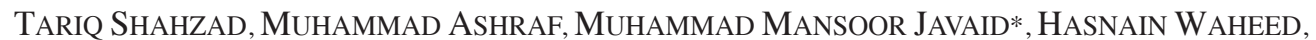 \\ TASAWER ABBAS, FENG-Min Li \& ABDUL SATTAR
}

\begin{abstract}
Drought is one of the commonly occurring environmental stresses, limiting crop production in many countries. Selection of cultivar is the most effective and economical means for alleviating the adverse effects of drought stress on crops. The present study aimed to investigate the growth, some physiological processes, yield and quality of some newly-developed wheat cultivars (AARI-2011, AAS-2011, Faisalabad-2008, Millat-2011 and Punjab-2011) under field drought stress conditions. The cultivars were sown in a field under normal irrigation and drought-induced conditions. Maximum net photosynthetic rate was recorded in cv. AAS-2011 at growth stage of 67 days after wheat emergence under normal irrigation and cv. Faisalabad-2008 at 67 days after wheat emergence under drought condition. Leaf stomatal conductance and transpiration rate were maximum in cv. Faisalabad-2008 under drought conditions. The adverse effects of drought stress were observed more on $\mathrm{cv}$. Millat-2011 than Faisalabad-2008, with respect to net photosynthetic rate and transpiration. Drought exerted a significant adverse effect on leaf stomatal conductance at 74 days after wheat emergence which was recorded as $230 \mathrm{mmol} \mathrm{m}^{-2} \mathrm{~s}^{-1}$. Among the cultivars, AAS-2011 recorded maximum yield traits and grain yield under normal irrigation condition and Faisalabad-2008 under drought condition. Cultivar Millat-2011 was the most susceptible to drought and Faisalabad-2008 the most resistant to drought. Faisalabad-2008 maintained the quality at the most under drought stress conditions. It is concluded that Fasialabad-2008 should be grown under field drought conditions to achieve maximal yield and quality of wheat.
\end{abstract}

Keywords: Photosynthetic activity; protein; starch; water deficit; wheat production

\section{ABSTRAK}

Kemarau merupakan salah satu tekanan alam sekitar yang biasanya berlaku yang mengehadkan pengeluaran tanaman di banyak negara. Pemilihan kultivar adalah cara yang paling berkesan dan bersifat ekonomi untuk mengurangkan kesan buruk daripada tekanan kemarau ke atas tanaman. Kajian ini bertujuan untuk mengkaji pertumbuhan, proses fisiologi, hasil dan kualiti kultivar gandum yang baru dibangunkan (AARI-2011, AAS-2011, Faisalabad-2008, Millat-2011 dan Punjab-2011) pada tanah yang bertekanan kemarau. Kultivar telah dicambah di padang yang tidak mempunyai pengairan yang baik serta telah teraruh-kemarau. Kadar bersih fotosintesis maksimum yang dicatatkan dalam cv. AAS2011 peringkat pertumbuhan 67 hari selepas kemunculan gandum di bawah pengairan biasa dan cv. Faisalabad-2008 peringkat pertumbuhan 67 hari selepas kemunculan gandum di bawah keadaan kemarau. Daun stomatal konduktans dan kadar transpirasi paling maksimum adalah tanaman cv. Faisalabad-2008 dalam keadaan kemarau. Kesan-kesan negatif disebabkan tekanan kemarau lebih terlihat kepada cv. Millat-2011 berbanding Faisalabad-2008, dari sudut kadar fotosintesis bersih dan transpirasi. Kemarau memberi impak negatif yang besar pada konduksi stomatal daun pada hari ke-74 selepas kemunculan gandum yang direkodkan ialah 230 mmol m-2 s-1. Kulvitar AAS-2011 mencatatkan ciri hasil dan hasil bijirin yang maksimum untuk pengairan yang lemah manakala kulvitar Faisalabad-2008 pula di dalam keadaan kemarau. Kultivar Millat-2011 adalah yang paling rentan dengan kemarau dan kultivar Faisalabad-2008 yang paling bertahan dengan kemarau. Kultivar Faisalabad-2008 masih berkualiti walaupun dalam keadaan kemarau. Kesimpulannya adalah kultivar Fasialabad-2008 perlu ditanam dalam keadaan kemarau untuk mencapai hasil dan kualiti gandum yang maksima.

Kata kunci: Aktiviti fotosintesis; defisit air; kanji; pengeluaran gandum; protein

\section{INTRODUCTION}

Drought stress is considered as one of the most common environmental cues limiting crop yield world-over (Ashraf
2010; Reddy et al. 2004). Usually, drought stress has detrimental effects on many processes in plants (Anjum et al. 2011) and the major targets of drought stress are key 
physiological processes such as photosynthesis in plants as well as quality of produce. Many reports have shown that drought stress in plants limits their photosynthesis through stomatal closure and metabolic impairment (Carmo-Silva et al. 2012; Chastain et al. 2014; Jie et al. 2013). Drought stress while disturbing the leaf photosynthesis and stomatal conductance (Pinheiro \& Chaves 2011) is believed to decrease assimilate synthesis which is apt for grain filling and consequently it results in grain shrinkage, yield losses and poor quality grains (BeNCze \& VeiSz 2011). Therefore, an efficient use of limited water resources under limited water supply along with good quality of grains is the desirable trait of most grain crops.

Generally, plant responses to physiological and biochemical of drought stress (Anjum et al. 2011) and types of observed responses may depend on stress intensity, stress duration, genotype, and environmental conditions (Rharrabti et al. 2003). Numerous studies have been carried out previously on wheat to evaluate the effects of genotypes, environmental stresses and their interactions (Beleggia et al. 2013; Denčić et al. 2011; Peterson et al. 1992; Shewry et al. 2010). However, the effects of such interactions have been rarely assessed with respect to grain quality. Quality parameters of wheat are believed to vary over a wide range among the cultivars under drought (BeNCze \& VeiSz 2011) and drought stress generally results in increasing wheat grain protein contents (Gooding et al. 2003) and reducing ash content (Rharrabti et al.2003). However, the grain protein quality is closely related to the type of cultivars (Nazco et al. 2012). In another study, Jie et al. (2013) showed that drought stress during grain filling stage caused reduced grain filling and earlier attainment of harvest maturity, which subsequently resulted in substantial changes in the protein composition of grains and size distribution of starch granules. Recently, Giuliani et al. (2014) reported marked differences in gliadin and gluten composition between water regimes and wheat cultivars.

Of the strategies to overcome the drought problem and improve the quality of grains, selection of cultivars is the most effective and economic means for alleviating the adverse effects of drought on growth, yield and quality of different crops. Cultivars within a species respond differently to different stresses in a particular area due to difference in their genetic makeup and regulation of physiological processes (Anderson 2010; Jahn et al. 2011).

Wheat possesses genetic variation at intra-specific and inter-specific levels for stress tolerance (Juenger 2013). A few field studies have shown that photosynthesis, some other related physiological traits and quality of wheat grains differ significantly within genotypes under water stress. Thus, the purpose of this study was to evaluate the effects of drought stress on growth, some physiological processes, yield and grain quality of some newly developed wheat cultivars under field drought stress conditions.

\section{MATERIALS AND METHODS}

A field experiment was conducted in the Research Area of the University College of Agriculture, University of Sargodha, Pakistan $\left(32^{\circ} \mathrm{N}, 72^{\circ} \mathrm{E}\right)$ during the 2013-2014 growing season. The soil of the experimental site was analyzed and found to be sandy clay loam with $\mathrm{pH} 8.2$, organic matter content was $0.90 \%, 0.56 \% \mathrm{~N}, 17.1 \mathrm{ppm}$ available $\mathrm{P}$ and $120 \mathrm{ppm}$ available K. Five newly developed wheat cultivars (AARI-2011, AAS-2011, Faisalabad-2008, Millat-2011, Punjab-2011) were used for this study which were obtained from Ayub Agricultural Research Institute, Faisalabad, Pakistan. The experiment was laid out in a randomized complete block design (RCBD) with a factorial arrangement, and each treatment was replicated four times. The plot size was $2 \mathrm{~m} \times 1.5 \mathrm{~m}$. Water regimes were: normal irrigation and drought-induced plot. Alternate irrigation was skipped to induce drought in drought plots. A measured quantity of $0.25 \mathrm{~m}^{3}$ per irrigation was applied to each plot where applicable. A wide ridge of $1 \mathrm{~m}$ was made between irrigated plots to prevent the seepage. The cultivars were planted on November 11, 2013 on a clay loam soil at field capacity level. The seeds were sown using a single row experimental drill in each plots consisting of six rows with a $25 \mathrm{~cm}$ row space and seeding rate for each plot was 425 seeds $\mathrm{m}^{-2}$ to obtain uniform stands. Broad leaf weeds were controlled with Buctril Super ${ }^{\circledR}$ (Bromoxynil + MCPA) at $750 \mathrm{~mL} \mathrm{ha}^{-1}$ and grass weeds with Puma Super® (Phenoxyporp p-ethyl) at $750 \mathrm{~mL} \mathrm{ha}^{-1}$. After 40 day of wheat sowing, each herbicide was applied once at the two-to-four-leaf stage of weeds with a backpack sprayer equipped with a flat-fan nozzle (Tee jet 8002E Nozzle, Spraying Systems Company, Wheaton, IL 60118) calibrated to deliver $250 \mathrm{~L} \mathrm{ha}^{-1}$ at a speed of $3.2 \mathrm{~km} \mathrm{~h}^{-1}$. Fertilizers were applied as: $30 \mathrm{~kg} \mathrm{ha}^{-1}$ nitrogen as urea, 85 $\mathrm{kg} \mathrm{ha}^{-1}$ phosphorus as triple super-phosphate and $60 \mathrm{~kg}$ $\mathrm{ha}^{-1}$ potassium as sulphate of potash at planting time and 30 and $40 \mathrm{~kg} \mathrm{ha}^{-1}$ nitrogen as urea were applied at the start and end of tillering, respectively. Water stressed plots were irrigated on December 28, 2013, whereas, normal irrigation applied plots were watered on December 28, 2013; January 01, 2014; and March 03, 2014. The total rainfall during the growing season was $100 \mathrm{~mm}$ (Figure 1).

\section{PHYSIOLOGICAL PARAMETERS}

The net photosynthesis rate, transpiration rate and stomatal conductance were measured using a portable infrared gas analyzer (CI-340 Portable Photosynthesis System, CID Biosciences, USA) with the following adjustments: Mass flow rate $0.33 \mathrm{~mol} \mathrm{~m}^{-2} \mathrm{~s}^{-1}$, atmospheric pressure $99.8 \mathrm{kPa}$, photosynthetically active radiation at leaf surface was maximum up to $1553 \mu \mathrm{mol} \mathrm{m} \mathrm{m}^{-2} \mathrm{~s}^{-1}$, water vapour pressure at the outlet of leaf chamber ranged from 1.9 to $3.7 \mathrm{kPa}$, temperature of the ambient air in the leaf chamber ranged from 23 to $34^{\circ} \mathrm{C}$ and temperature of leaf ranged from 24 to $32^{\circ} \mathrm{C}$. The physiological parameters were recorded for five times during the growing season of the wheat crop. The first measurement of the physiological parameters was started 
at 60 days after emergence (DAE) and the measurement was taken five times with an interval of seven days. The measurements were recorded in between 10:00 am and 12:00 pm and fully extended flag leaves were selected for measurements.

\section{AGRONOMIC TRAITS}

The spike bearing and non-spike bearing tillers of wheat plants were counted in an area of $1 \mathrm{~m}^{2}$ when the spikes fully emerged from the flag leaf sheath. Ten spikes were harvested from each plot and then threshed to count grain number per spike. The middle four rows of each plot were harvested from each treatment to calculate biological and grain yield on April 20, 2014 and grain yield adjusted to $12 \%$ moisture content. The thousand grain weight from each plot was randomly counted and the weight recorded using an electric balance. Drought susceptibility index (DSI) and relative yield potential (RY) were calculated using the mean grain yield. The DSI was calculated according to the formula of Fischer and Maurer (1978).

$$
\mathrm{DSI}=\frac{1-\left(\frac{Y D}{Y N}\right)}{D}
$$

where YD is the mean yield under drought conditions; YN is the mean yield under normal irrigation conditions and D is the environmental stress intensity that was calculated as (1-(mean yield of all genotypes under drought conditions/ mean yield of all genotypes under normal irrigation conditions).

The relative yield under normal irrigation or drought conditions was calculated as the yield of a specific genotype under normal or drought conditions divided by the highest yielding genotype in the respective condition population.

\section{QUALITY PARAMETERS}

All the samples were stored at room temperature $\left(25^{\circ} \mathrm{C}\right)$. The ash content of wheat grains was obtained according to the STAS 90-1988 method (Bordei et al. 2007). NIR spectroscopy method was used for the determination of protein, moisture, starch, gluten, fat and fiber contents. The wheat samples were analyzed with the workhorse of Bruins Instrument NIR grain analyzer $\mathrm{G}^{\mathrm{TM}}$. The spectral transmission range was between 730 and $1100 \mathrm{~nm}$ and source increment $5 \mathrm{~nm}$. All samples were stored at room temperature.

\section{STATISTICAL ANALYSIS}

Data were subjected to two-way ANOVA with PROC GLM in SAS 9.0 (SAS 2002) and means separated with Fisher's protected LSD at $P<0.05$ level of probability (Steel et al. 1997).

\section{RESULTS AND DISCUSSION}

\section{EFFECT ON PHYSIOLOGICAL PARAMETERS}

All cultivars showed reduced net photosynthetic rate under water deficit regimes (Figure 2(a) \& 2(b)). Under drought conditions, there was no significant difference among the cultivars in net photosynthetic rate from 60 to 67 DAE (Figure 2(b)), however, it increased with increase in growth from 67 to 74 DAE and decreased significantly from 74 to 81 or 88 DAE. The trend of increase or decrease in net photosynthesis rate over growth stage was different under normal irrigation conditions from that under drought conditions. Net photosynthetic rate of all cultivars increased with increase in growth from 67 to 74 DAE except AARI-2011, which showed a static net photosynthetic rate up to growth stage of $74 \mathrm{DAE}$ and after that it showed a significant increase in net

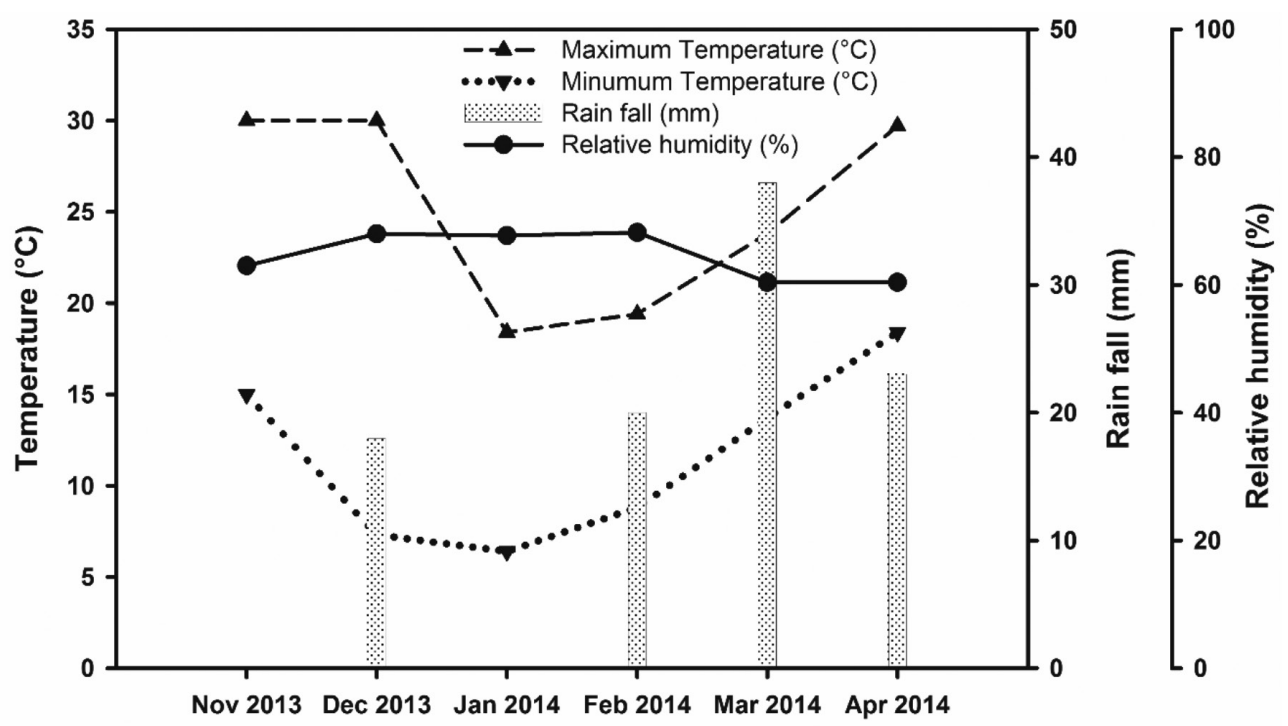

FIGURE 1. Climatic conditions during the growing season of wheat crop 
photosynthetic rate (Figure 2(a). Net photosynthetic rate of Faisalabad-2008, Punjab-2011 and Millat-2011 decreased when growth increased from 74 to 81 DAE, whereas AAS-2011 recorded the same net photosynthesis rate at 74 and 81 DAE. Maximal net photosynthetic was recorded at 67 DAE in AAS-2011 $\left(7.7 \mu \mathrm{mol} \mathrm{m}^{-1} \mathrm{~s}^{-1}\right)$ and at 74 DAE in Faisalabad-2008 $\left(6.1 \mu \mathrm{mol} \mathrm{m}^{-1} \mathrm{~s}^{-1}\right)$ (Figure 2(a) \& 2(b)).

At 60 DAE of wheat, maximum reduction (from 5.7 to $4.8 \mu \mathrm{mol} \mathrm{m} \mathrm{m}^{-1} \mathrm{~s}^{-1}$ ) in net photosynthetic rate was recorded in cvs. Millat-2011 and AAS-2011 under drought stress. Similarly, at $67 \mathrm{DAE}$, a significant reduction in net photosynthetic rate was recorded in all the cultivars due to drought stress and most affected cultivars were AAS-2011, Millat-2011 and Punjab-2011 under drought stress in comparison with normal irrigation conditions. Except AARI-2011, all the cultivars under drought conditions showed reduction in net photosynthetic rate at 74 DAE with respect to normal irrigation conditions. Whereas, all the cultivars markedly showed decreased net photosynthetic rate at 81 and 87 DAE when subjected to drought conditions (Figure 2(a) \& 2(b)).

Drought stress caused significant adverse effects on leaf stomatal conductance in all cultivars (Figure 3(a) \& 3(b)). Data showed that leaf stomatal conductance of all the cultivars at 60 DAE ranged from 200 to $260 \mathrm{mmol}$ $\mathrm{m}^{-2} \mathrm{~s}^{-1}$ under normal irrigation conditions, but drought caused its reduction to $175 \mathrm{~m}^{-2} \mathrm{~s}^{-1}$ at this stage. Stomatal conductance of the cultivars under normal irrigation conditions did not increase with increase in growth from 60 to 67 DAE, however, it increased thereafter (at 74 DAE growth stage). Under drought conditions, leaf stomatal conductance increased slightly in all the cultivars with increase in growth from 60 to 74 DAE. After 74 DAE, leaf stomatal conductance of the cultivars obtained their maximal values when growth reached at $81 \mathrm{DAE}$, but decreased again with increase in growth period (Figure $3(b))$. All the cultivars attained a maximal leaf stomatal conductance at 74 DAE under normal irrigation conditions and at 81 DAE under drought conditions (Figure 3(a) \& 3(b)). Drought exerted maximal effects on leaf stomatal conductance at $74 \mathrm{DAE}$ as it reduced stomatal conductance up to $230 \mathrm{mmol} \mathrm{m}^{-2} \mathrm{~s}^{-1}$ in the cultivars. Among the cultivars, maximum and minimum reductions in leaf stomatal conductance were recorded in cvs. AAS-2011 and Fasialabad-2008 due to drought stress when compared to that under normal irrigation conditions. Cultivar AAS2011 pre formed excellently under normal irrigation conditions and cv. Faislabad-2008 under drought conditions in terms of leaf stomatal conductance (Figure 3(a) \& 3(b)).

Significant difference was recorded in transpiration rate of different cultivars under drought conditions when compared to that under normal irrigation conditions (Figure 4(a) \& 4(b)). Under normal irrigation conditions, transpiration rate of the cultivars progressively increased

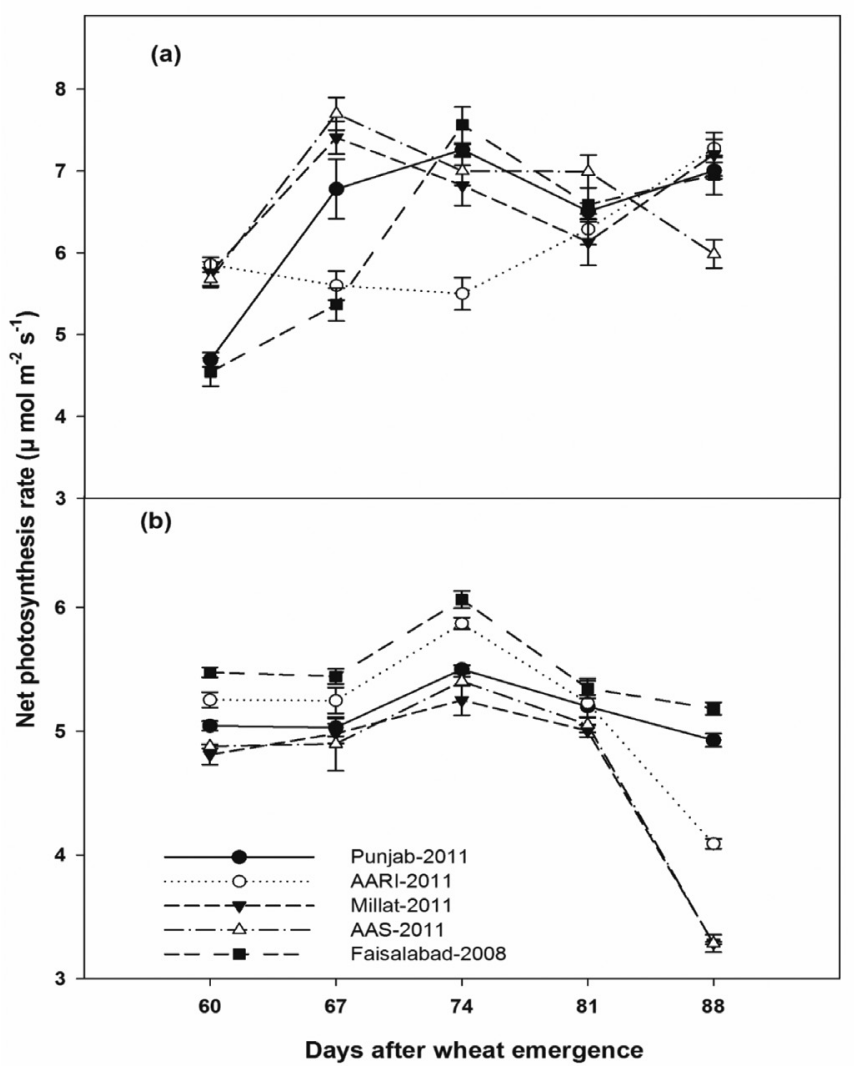

FIGURE 2. Net photosynthesis rate of wheat cultivars at different growth stages under normal irrigation (a) and drought conditions (b) Vertical bar for each point is standard error of the mean 
to their maximum values with increase in growth from 60 to 74 DAE, but when the wheat crop reached at growth stage of 81 DAE, transpiration rate markedly decreased. However, a slight increase in transpiration rate was recorded with increase in growth from 81 to 88 DAE. Under drought conditions, transpiration rate increased with increase in growth from 60 to 67 DAE (Figure 4(b)). After $67 \mathrm{DAE}$, the reduction in transpiration rate was recorded at all growth stages with increase in growth due to drought stress. Drought exerted maximum effects on transpiration rate at 60 and $88 \mathrm{DAE}$ as it caused reduction in transpiration rate up to $2.8 \mathrm{mmol} \mathrm{m}^{-2} \mathrm{~s}^{-1}$ in the cultivars.

Performance of the cultivars in terms of transpiration rate varied under normal irrigation and drought conditions (Figure 4(a) \& 4(b)). The transpiration rate of $\mathrm{cv}$. Faisalabad-2008 at 60,67,74 and 88 DAE was the least affected due to drought conditions when compared to that under normal irrigation conditions, while that of cv. Millat-2011 at 60,67,74 and 88 DAE was the most affected due to drought stress. At 80 DAE, maximum and minimum reductions in transpiration rate were recorded in Punjab-2011 and AARI-2011 due to drought conditions, respectively. The maximum transpiration rate under normal irrigation was recorded in cv. Millat-2011 (4.3 $\left.\mathrm{mmol} \mathrm{m} \mathrm{m}^{-2} \mathrm{~s}^{-1}\right)$ at $88 \mathrm{DAE}$ and under drought conditions in cv. Faisalabad-2008 (2.3 $\left.\mathrm{mmol} \mathrm{m}^{-2} \mathrm{~s}^{-1}\right)$ at $67 \mathrm{DAE}$ (Figure 4(a) \& 4(b)).

\section{EFFECT ON AGRONOMIC TRAITS}

Number of productive tillers $\left(\mathrm{m}^{-2}\right)$ of all the cultivars decreased significantly under drought conditions as normal irrigation conditions produced $16 \%$ more productive tillers as compared to the drought conditions (Table 1). Among the cultivars, maximum number of productive tillers was recorded in cv. AAS-2011 (419) under normal irrigation, whereas cv. Faisalabad-2008 produced maximum number of productive tillers (345) under drought conditions. Normal irrigation conditions resulted in $18 \%$ larger spikes in length to that under drought conditions. Cultivar AAS2011 showed maximum plant height $(98 \mathrm{~cm})$ and spike length $(14 \mathrm{~cm})$ under normal and drought conditions. However, of the tested cultivars, cv. Millat-2011 showed minimum plant height and spike length under drought stress. Drought conditions had significant adverse effects on number of grains per spike, 1000-grains weight, biological yield and grain yield. It is evident from the data that normal irrigation conditions resulted in 31, 7, 30 and $25 \%$ more number of grains per spike, 1000 -grians weight, biological yield and grain yield, respectively, as compared to those under drought conditions. Under normal irrigation conditions, of the tested cultivars, the performance of cv. AAS-2011 was superb in terms of the highest number of grains per spike, 1000-grain weight, biological yield and grain yield. Whereas under drought conditions, cv. Faisalabad-2008 produced maximum number of grains

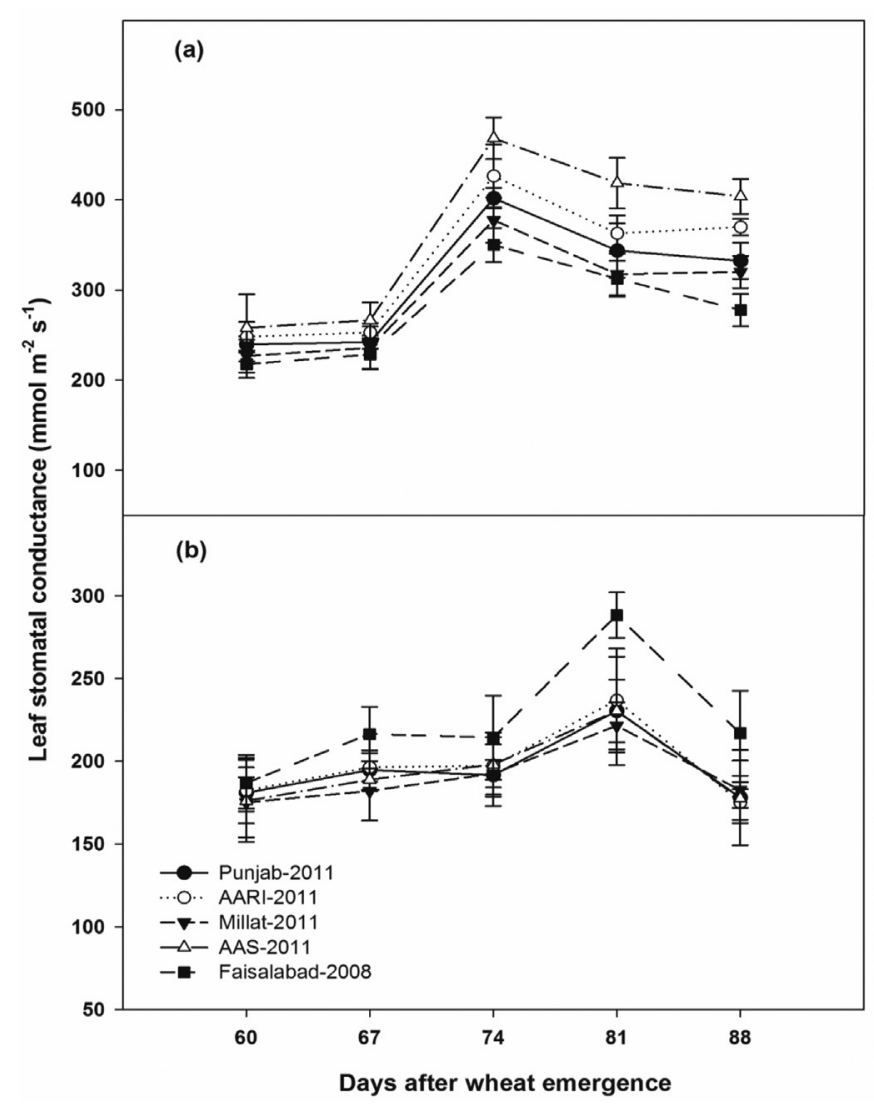

FIGURE 3. Leaf stomatal conductance of wheat cultivars at different growth stages under normal irrigation (a) and drought conditions (b). Vertical bar for each point is standard error of the mean 
per spike, 1000-grain weight, biological yield and grain yield (Tables $1 \& 2$ ).

The mean relative yield (RY) under normal and drought conditions was 0.91 and 0.92 , respectively. Cultivars Punjab-2011, AARI-2011 and AAS-2011 were relatively high yielding (RY > mean RY) under normal irrigation conditions. However, cultivars Punjab-2011, AARI-2011, AAS-2011 and Faisalabad-2008 were high yielding (RY > mean RY) under drought conditions, while cv. Millat-2011 was relatively low yielding $(\mathrm{RY}<\mathrm{mean} \mathrm{RY})$. Drought susceptibility index value for the yield ranged from 0.21 to 1.36 (Table 2). Among the cultivars, Punjab-2011, AARI-2011, Millat-2011 and AAS-2011 were drought susceptible (DSI value $>1$ ), while cultivar Faisalabad-2008 drought resistant (DSI value $<1$ ).

\section{EFFECT ON GRAIN QUALITY PARAMETERS}

Data for quality parameters of grains of the wheat cultivars as affected by irrigation conditions is presented in Figures 5 and 6. Drought conditions caused considerable reduction in the quality parameters (moisture, starch, fat, fiber and falling numbers) of all the wheat cultivars compared with those under normal irrigation conditions. However, the performance of the cultivars with respect to quality varied under both irrigation conditions. Drought conditions significantly increased the grain protein contents compared with normal irrigation conditions in cultivars, except Faisalabad-2008 (Figure 5(a)). Similarly, wet gluten contents of AARI-2011, Millat-2011 and AAS2011 increased by $2.7,4.0$ and $4.7 \%$, respectively, due to drought stress. Ash contents of cvs. Punjab-2011, AARI2011, Millat-2011 and AAS-2011 increased from 0.5 to $0.7 \%$ due to drought stress (Figure 6(b)). Under normal irrigation conditions, maximum starch $(58.6 \%)$ and fat contents $(2.2 \%)$ were recorded in cv. AAS-2011, while under drought conditions these were maximum $(53 \%$ starch and $1.8 \%$ fat) in cv. Faisalabad-2008 (Figure 5(c), $5(\mathrm{~d}))$. Low amount of moisture contents $(11.4 \%)$ was

TABLE 1. Effect of irrigation conditions on growth and yield components of selected cultivars of wheat

\begin{tabular}{|c|c|c|c|c|c|c|c|c|}
\hline \multirow{3}{*}{ Cultivars } & \multicolumn{8}{|c|}{ Irrigation conditions } \\
\hline & \multicolumn{2}{|c|}{ Productive tillers $\left(\mathrm{m}^{-2}\right)$} & \multicolumn{2}{|c|}{ Plant height $(\mathrm{cm})$} & \multicolumn{2}{|c|}{ Spike length $(\mathrm{cm})$} & \multicolumn{2}{|c|}{ No. of grains per spike } \\
\hline & Normal & Drought & Normal & Drought & Normal & Drought & Normal & Drought \\
\hline Punjab-2011 & $377 a b c$ & 306 de & $84 \mathrm{bc}$ & $87 \mathrm{~b}$ & $13 \mathrm{~b}$ & $9.5 \mathrm{~cd}$ & $77 \mathrm{~b}$ & $55.2 \mathrm{~cd}$ \\
\hline AARI-2011 & $380 \mathrm{ab}$ & 322 cde & $87 \mathrm{~b}$ & $87 \mathrm{~b}$ & $11 \mathrm{bcd}$ & $9.123 \mathrm{~d}$ & $78 \mathrm{~b}$ & $59 \mathrm{~cd}$ \\
\hline Millat-2011 & $359 \mathrm{bcd}$ & $295 \mathrm{e}$ & $87 \mathrm{~b}$ & $81 \mathrm{c}$ & $10 \mathrm{~cd}$ & $8.8 \mathrm{~d}$ & $76 \mathrm{~b}$ & $40 \mathrm{~d}$ \\
\hline AAS-2011 & $419 \mathrm{a}$ & $301 \mathrm{e}$ & $98 \mathrm{a}$ & $98 \mathrm{a}$ & $14 \mathrm{a}$ & $11.9 \mathrm{abc}$ & $92 \mathrm{a}$ & $52.3 \mathrm{de}$ \\
\hline Faisalabad-2008 & 339 bcde & 345 bcde & $86 \mathrm{bc}$ & $89 \mathrm{~b}$ & $10 \mathrm{~cd}$ & $9.8 \mathrm{~cd}$ & $67 \mathrm{bc}$ & $59.2 \mathrm{~cd}$ \\
\hline Means & 375 & 314 & 88 & 88 & 12 & 9.8 & 78 & 53.1 \\
\hline$\%$ Differences & \multicolumn{2}{|c|}{+16.2} & \multicolumn{2}{|c|}{0.0} & \multicolumn{2}{|c|}{18.3} & \multicolumn{2}{|c|}{+31.9} \\
\hline LSD $(0.05)$ & \multicolumn{2}{|c|}{56.6} & \multicolumn{2}{|c|}{5.23} & \multicolumn{2}{|c|}{2.53} & \multicolumn{2}{|c|}{12.72} \\
\hline
\end{tabular}

TABLE 2. Effect of irrigation conditions on yield component, yield, relative yield and drought susceptibility index of selected cultivars of wheat

\begin{tabular}{|c|c|c|c|c|c|c|c|c|c|}
\hline \multirow{3}{*}{ Cultivars } & \multicolumn{8}{|c|}{ Irrigation conditions } & \multirow{3}{*}{ DSI } \\
\hline & \multicolumn{2}{|c|}{$\begin{array}{l}\text { 1000-grains } \\
\text { weight }(\mathrm{g})\end{array}$} & \multicolumn{2}{|c|}{$\begin{array}{l}\text { Biological yield } \\
\quad\left(\mathrm{kg} \mathrm{ha}^{-1}\right)\end{array}$} & \multicolumn{2}{|c|}{$\begin{array}{l}\text { Grain yield } \\
\left(\mathrm{kg} \mathrm{ha}^{-1}\right)\end{array}$} & \multicolumn{2}{|c|}{ Relative yield } & \\
\hline & Normal & Drought & Normal & Drought & Normal & Drought & Normal & Drought & \\
\hline Punjab-2011 & $32.87 \mathrm{bc}$ & $30.75 \mathrm{de}$ & $15833 \mathrm{ab}$ & $10917 \mathrm{~cd}$ & $4975.0 \mathrm{ab}$ & $3666.7 \mathrm{c}$ & 0.94 & 0.93 & 1.05 \\
\hline AARI-2011 & $34.62 \mathrm{ab}$ & $31.62 \mathrm{~cd}$ & $16333 \mathrm{a}$ & $11167 \mathrm{~cd}$ & $5000.0 \mathrm{ab}$ & $3708.0 \mathrm{c}$ & 0.94 & 0.94 & 1.03 \\
\hline Millat-2011 & $30.25 \mathrm{def}$ & $27.75 \mathrm{~g}$ & $15333 a b$ & $9583 \mathrm{~cd}$ & $4933.3 \mathrm{ab}$ & $3250.0 \mathrm{c}$ & 0.93 & 0.82 & 1.36 \\
\hline AAS-2011 & $36.37 \mathrm{a}$ & $28.75 \mathrm{fg}$ & 16667 a & $10417 \mathrm{~d}$ & 5316.7 a & $3583.3 \mathrm{c}$ & 1.0 & 0.91 & 1.30 \\
\hline Faisalabad-2008 & 29 efg & $33 \mathrm{bc}$ & $14333 \mathrm{~b}$ & $12000 \mathrm{c}$ & $4166.7 \mathrm{abc}$ & $3950.3 \mathrm{bc}$ & 0.78 & 1.0 & 0.21 \\
\hline Means & 32.62 & 30.32 & 15733 & 10866.4 & 4878.3 & 3658.3 & 0.91 & 0.92 & \\
\hline$\%$ Differences & \multicolumn{2}{|c|}{+7.1} & \multicolumn{2}{|c|}{+30.9} & \multicolumn{2}{|c|}{+25.0} & & & \\
\hline $\operatorname{LSD}(0.05)$ & \multicolumn{2}{|c|}{1.85} & \multicolumn{2}{|c|}{1668.5} & \multicolumn{2}{|c|}{1182} & & & \\
\hline
\end{tabular}

Data was subjected to two-way ANOVA analysis. Means sharing the same letters within the column did not differ significantly at $5 \%$ level of probability.. RY $=$ relative yield, DSI $=$ drought susceptibility index 


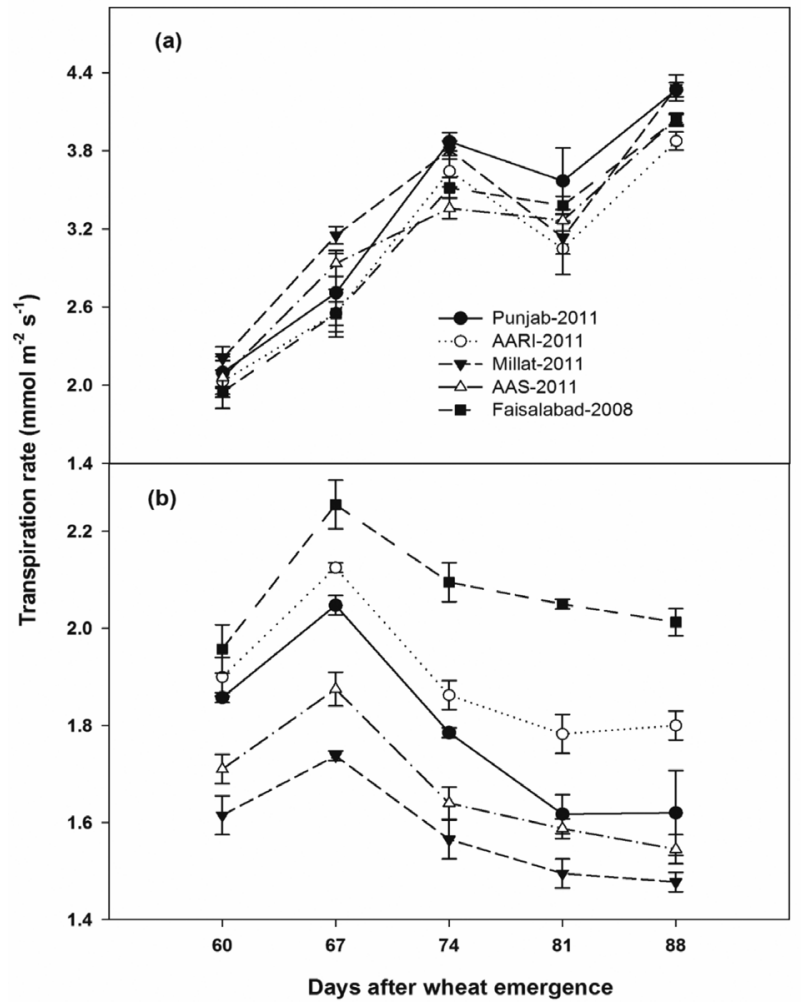

FIGURE 4. Transpiration rate of wheat cultivars at different growth stages under normal irrigation (a) and drought conditions (b).

Vertical bar for each point is standard error of the mean

recorded in cv. Millat-2011 under drought conditions and there was no significant difference among the cultivars under normal irrigation conditions (Figure 5(b)). Cultivar AAS-2011 showed maximum fiber $(2.4 \%)$ and falling number (592.3) under normal irrigation conditions (Figure $6)$. Under drought conditions, the performance of cv. Faislalabad-2008 was excellent among the cultivars and it recorded maximum fiber (2.0\%) and falling number (493.6) as well as minimum ash contents $(1.7 \%)$. Drought exerted adverse effects on cv. AAS-2011 in terms of starch, fat and fiber contents. However, minimum effects were observed in cv. Faisalabad-2008 which showed only $0.2 \%$ less fiber contents. Drought conditions did not affect the starch and fat contents in Faisalabad-2008 and wet gluten contents in Punjab-2011.

The mechanism of drought tolerance differs among species and even among cultivars of a single species. We compared the growth, some key physiological traits and grain yield and quality of newly-developed wheat cultivars under normal irrigation and drought conditions. The photosynthetic activities are the primary determinants for crop productivity and increasing photosynthesis rate has been recognized as a key trait to increased crop yields (Driever et al. 2014; Raines 2011; Rybka \& Nita 2015). In our study, the cultivars varied in gas exchange activities under normal irrigation conditions. Differences in gas exchange activities of the cultivars might be due to natural genetic variation. Several studies have earlier

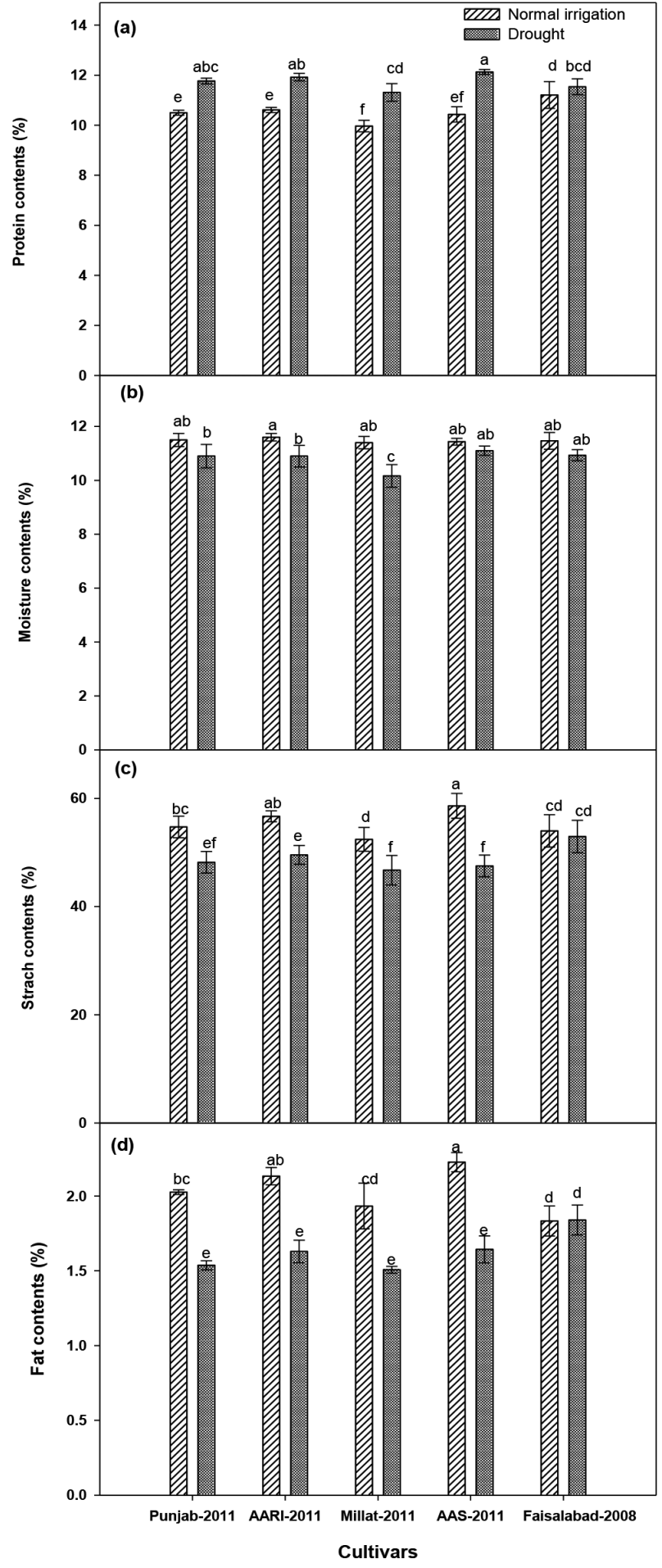

FIGURE 5. Protein (a), moisture (b), starch (c) and fat contents (d) of grains of wheat cultivars under normal irrigation and drought conditions. Nail on the bar represents standard error of the mean

reported natural variation in photosynthetic capacity among different species (Driever et al. 2014; Hikosaka \& Shigeno 2009; Lawson et al. 2012), however, there were other studies which have shown natural variation within individual crop species (Flood et al. 2011; Gilbert et al. 2011; Gu et al. 2014; Lawson \& Blatt 2014). Our results showed that drought stress exerted significant 

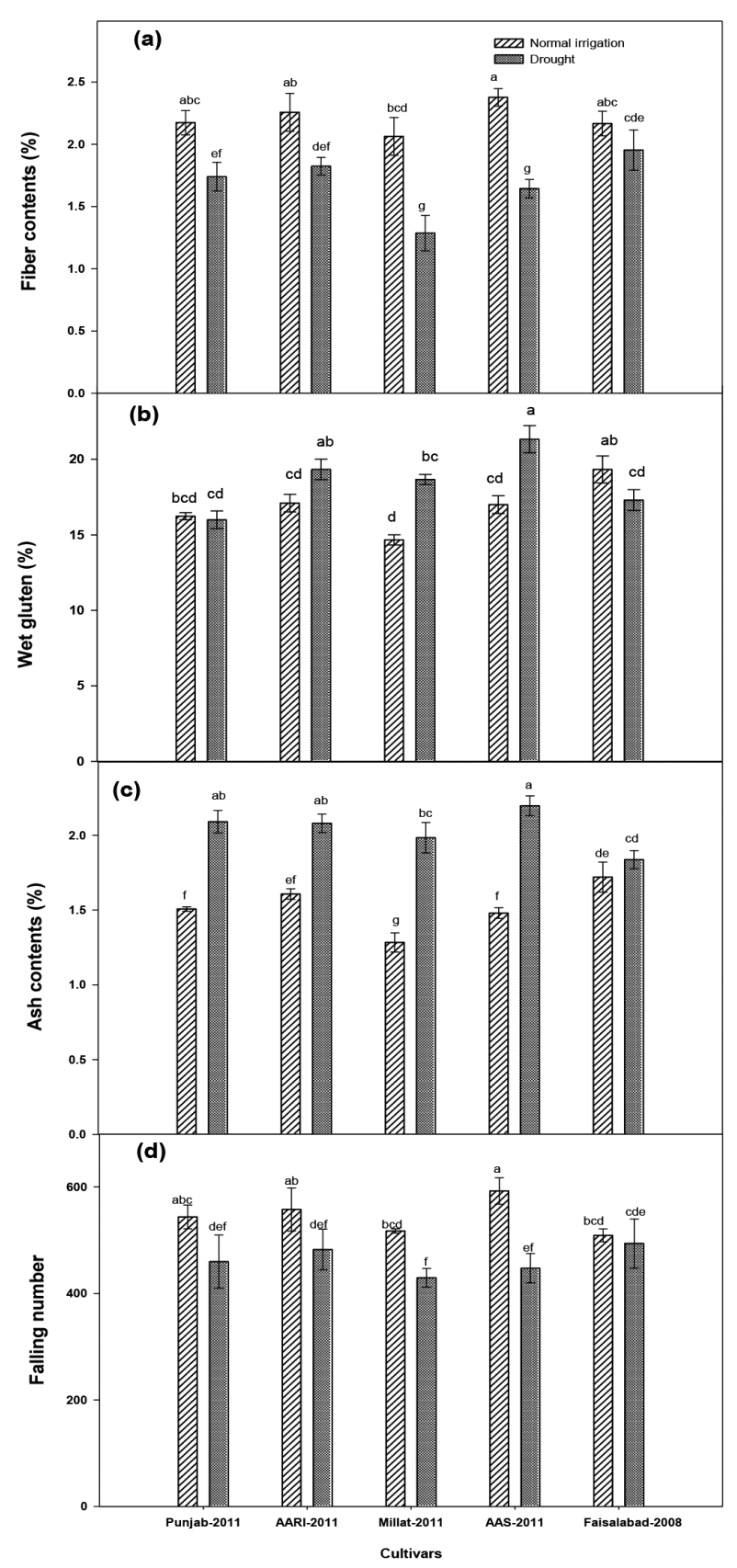

FIGURE 6. Fiber contents (a), wet gluten contents (b), ash contents (c) and falling number (d) of grains of wheat cultivar under normal irrigation and drought conditions. Nail on the bar represents standard error of the mean

adverse effects on net photosynthetic rate, leaf stomatal conductance and transpiration rate. This might have showed that drought stress has a direct impact on the photosynthetic activities by disrupting all major components due to stomatal closure that reduced $\mathrm{CO}_{2}$ uptake under drought conditions. Early reports of photosynthesis include carbon reduction cycle, thylakoid electron transport, stomatal control of the $\mathrm{CO}_{2}$ supply and disturbance of water balance (Shukla et al. 2015; Vandoorne et al. 2012). In fluctuating environmental conditions or environmental stress, stomatal and photosynthetic responses of plants differ especially under changing light and temperature conditions which lag in stomatal behavior and limit photosynthetic activity (Lawson et al. 2011; Lawson \& Blatt 2014). It is well documented that wheat cultivars grown in water-limited conditions show natural genetic variation in traits related to drought tolerance. Therefore, the ability to maintain functionality of the photosynthetic activities under drought stress is of major importance. The gas exchange activities of Faisalabad-2008 were the least affected due to drought stress, which might have been due to its higher potential for drought escape than that of others. Reduction in physiological processes like net photosynthetic rate, leaf stomatal conductance and transpiration rate varied among the species under drought conditions. This might have been due to differential genetic potential, chlorophyll contents and adaptation to drought (Ashraf \& Harris 2013; Chaves et al. 2009). Drought had a minimal or no effect on photosynthetic activities in the cultivars at initial growth stage (up to $60 \mathrm{DAE}$ ). The cultivars recorded maximum photosynthetic rate, stomatal conductance and transpiration rate at 67,74 and 88 DAE under normal irrigation conditions, while at 74, 81 and 88 DAE under drought conditions, respectively. A significant correlation has been reported between growth stages and gas exchange activities under different irrigation regimes ( $\mathrm{Gu}$ et al. 2012). Shangguan et al. (2004) reported that photosynthetic process under drought conditions is possible due to the osmoregulation which affects leaf stomata and adaptation of the photosynthetic apparatus to drought stress.

Drought stress reduced the productive tillers, plant height, spike length, number of grains per spike and 1000-grian weight which resulted in reduced normal growth, development and final grain yield. The differential response of the different wheat cultivars to drought or normal irrigation conditions might have been due to their differential genetic potential to the prevalent conditions. Previous studies have shown that severe water stress from seedling to maturity reduced gas exchange activities and grain yield components in wheat, especially photosynthesis, stomatal conductance, productive tillers per unit area, number of grains per spike and 1000-grain weight (Ahmed et al. 2007; Kilic \& Yagbasanlar 2010; Nouri-Ganbalani et al. 2009; Shukla et al. 2015). However, it is shown that among the cultivars, Faisalabad-2008 maintained its superior performance and produced maximum yield under drought conditions. This cultivar with good yield potential differed in its yield components from the other cultivars under the study. Under drought conditions, Faisalabad-2008 had the highest gas exchange activities, productive tillers, number of grains per spike and 1000-grains weight. Some studies have depicted that number of grains per spike and grain weight are the typical yield components that are the most sensitive to drought (Ahmed et al. 2007; Pradhan et al. 2012). These yield components have been suggested as prospective selection criteria for drought tolerance (Ahmed et al. 2007). Leilah and Al-Khateeb (2005) showed that productive tillers and grains per unit area to be genetically correlated to final grain yield under 
drought conditions. Drought susceptibility index values for yield varied among the cultivars and Faisalabad-2008 were found to be relatively drought resistant. Soil drought stress caused many changes in the wheat cultivars, resulting in decrease in photosynthetic activities and functioning of antioxidant enzymes. In the relatively drought resistant cv. Faisalabad-2008, fewer changes in net photosynthetic rate, stomatal conductance and transpiration rate indicated the capacity to protect the photosynthetic apparatus from drought-induced damage. This indicated that defense mechanism might have prevented this cultivar from suffering from irreversible damage due to drought and consequently maintained growth and yield almost similar to that under normal irrigation conditions. The drought sensitive cv. Millat-2011 showed considerable decrease in photosynthetic activities and final yield. The results of the study are in line with the early findings of Ahmed et al. (2007) and Kilic and Yagbasanlar (2010) who reported considerable variation in relative yield and drought susceptibility index of wheat genotypes under drought stress conditions.

Our study showed high influence of drought stress on a number of quality traits of bread wheat. Mean grain protein contents of Punjab-2011, AARI-2011, Millat-2011 and AAS2011 increased by $1.26,1.30,1.34$ and $1.70 \%$, respectively, under drought conditions. This is in agreement with the findings of Ozturk and Aydin (2004) on bread wheat who found a positive effect of drought on grain protein and wet gluten contents. Wet gluten contents of AARI-2011, Millat-2011 and AAS-2011 increased by 2.7,4.0 and 4.7\%, respectively, due to drought stress. Increase in gluten contents has already been previously reported by Flagella et al. 2010 and Hajheidari et al. 2007. The higher wet gluten contents might have been due to higher protein contents under drought conditions. Flagella et al . (2010) and SaintPierre et al. (2008) reported an increase in gluten content under drought conditions, consistent with an increase in protein contents. Drought had significant negative effects on starch, fat, fiber, ash contents and falling number in all the cultivars except Faisalabad-2008 which proved to be resistant in these traits against drought stress when compared with normal irrigation conditions. These results are in agreement with those reported earlier (Guedira et al. 2002; Ozturk \& Aydin 2004; Rharrabti et al. 2003). The overall decrease in yield and quality due to drought was found to be decreased in photosynthetic activities which in turn resulted in decreased yield and quality. However, the degree of reduction in yield and quality varied among the cultivars.

\section{CONCLUSION}

The present study showed that drought stress caused a considerable adverse effect on the quantity and quality of all the wheat cultivars examined. Of all the cultivars, Faisalabad-2008 showed superior performance in terms of photosynthetic activities, grain yield and quality under drought conditions.

\section{REFERENCES}

Ahmed, N., Chowdhry, M.A., Khaliq, I. \& Maekawa, M. 2007. The inheritance of yield and yield components of five wheat hybrid populations under drought conditions. Indonesia Journal of Agricultural Science 8: 53-59.

Anderson, W. 2010. Closing the gap between actual and potential yield of rainfed wheat. The impacts of environment, management and cultivar. Field Crops Research 116: 14-22.

Anjum, S.A., Xie, X.Y., Wang, L., Saleem, M.F., Man, C. \& Lei, W. 2011. Morphological, physiological and biochemical responses of plants to drought stress. African Journal of Agricultural Research 6: 2026-2032.

Ashraf, M. 2010. Inducing drought tolerance in plants: Recent advances. Biotechnology Advances 28: 169-183.

Ashraf, M. \& Harris, P. 2013. Photosynthesis under stressful environments: An overview. Photosynthetica 51: 163-190.

Bordei, D., Bahrim, G., Pâslaru, V., Gasparotti, C., Elizei, A., Banu, I., Ionescu, L. \& Codină, G. 2007. Determinarea proprietatilor de panificatie ale fainii. In Controlul Calitatii in Industria Panificatiei. Metode de Analiza, edited by Bordei, D. Romania: Academica Galati. pp. 343-445.

Beleggia, R., Platani, C., Nigro, F., De Vita, P., Cattivelli, L. \& Papa, R. 2013. Effect of genotype, environment and genotype-by-environment interaction on metabolite profiling in durum wheat (Triticum durum Desf.) grain. Journal of Cereal Sciences 57: 183-192.

BeNCze, S. \& VeiSz, O. 2011. Quality of winter wheat in relation to heat and drought shock after anthesis. Czech Journal of Food Science 29: 117-128.

Carmo-Silva, A.E., Gore, M.A., Andrade-Sanchez, P., French, A.N., Hunsaker, D.J.\& Salvucci, M.E. 2012. Decreased $\mathrm{CO}_{2}$ availability and inactivation of Rubisco limit photosynthesis in cotton plants under heat and drought stress in the field. Environmental and Experimental Botany 83: 1-11.

Chastain, D.R., Snider, J.L., Collins, G.D., Perry, C.D., Whitaker, J. \& Byrd, S.A. 2014. Water deficit in field-grown Gossypium hirsutum primarily limits net photosynthesis by decreasing stomatal conductance, increasing photorespiration, and increasing the ratio of dark respiration to gross photosynthesis. Journal of Plant Physiology 171: 1576-1585.

Chaves, M., Flexas, J. \& Pinheiro, C. 2009. Photosynthesis under drought and salt stress: Regulation mechanisms from whole plant to cell. Annual of Botany 103: 551-560.

Denčić, S., Mladenov, N. \& Kobiljski, B. 2011. Effects of genotype and environment on breadmaking quality in wheat. International Journal of Plant Production 5: 71-82.

Driever, S.M., Lawson, T., Andralojc, P., Raines, C.A. \& Parry, M. 2014. Natural variation in photosynthetic capacity, growth, and yield in 64 field-grown wheat genotypes. Journal of Experimental Botany 65: 4959-4973.

Fischer, R.A. \& Maurer, R. 1978. Drought resistance in spring wheat cultivars. I. Grain yield response. Australian Journal of Agricultural Research 29: 897-907.

Flagella, Z., Giuliani, M.M., Giuzio, L., Volpi, C. \& Masci, S. 2010. Influence of water deficit on durum wheat storage protein composition and technological quality. Eurepean Journal of Agronomy 33: 197-207.

Flood, P.J., Harbinson, J. \& Aarts, M.G. 2011. Natural genetic variation in plant photosynthesis. Trends in Plant Sciences 16: 327-335.

Gilbert, M.E., Zwieniecki, M.A. \& Holbrook, N.M. 2011. Independent variation in photosynthetic capacity and stomatal conductance leads to differences in intrinsic water use 
efficiency in 11 soybean genotypes before and during mild drought. Journal of Experimental Botany 62: 2875-2887.

Giuliani, M.M., De Santis, M.A., Pompa, M., Giuzio, L. \& Flagella, Z. 2014. Analysis of gluten proteins composition during grain filling in two durum wheat cultivars submitted to two water regimes. Italian Journal of Agronomy 9: 15-19.

Gooding, M., Ellis, R., Shewry, P. \& Schofield, J. 2003. Effects of restricted water availability and increased temperature on the grain filling, drying and quality of winter wheat. Journal of Cereal Science 37: 295-309.

Gu, J., Yin, X., Stomph, T.J. \& Struik, P.C. 2014. Can exploiting natural genetic variation in leaf photosynthesis contribute to increasing rice productivity? A simulation analysis. Plant \& Cell Environment 37: 22-34.

Gu, J., Yin, X., Struik, P.C, Stomph, T.J. \& Wang, H. 2012.Using chromosome introgression lines to map quantitative trait loci for photosynthesis parameters in rice (Oryza sativa L.) leaves under drought and well-watered field conditions. Journal of Experimental Botany 63: 455-469.

Guedira, M., McCluskey, P.J., MacRitchie, F. \& Paulsen, G.M. 2002. Composition and quality of wheat grown under different shoot and root temperatures during maturation. Cereal Chemistry 79: 397-403.

Hajheidari, M., Eivazi, A., Buchanan, B.B., Wong, J.H., Majidi, I. \& Salekdeh, G.H. 2007. Proteomics: Uncovers a role for redox in drought tolerance in wheat. Journal of Protection and Research 6: 1451-1460.

Hikosaka, K. \& Shigeno, A. 2009. The role of Rubisco and cell walls in the interspecific variation in photosynthetic capacity. Oecologia 160: 443-451

Jahn, C.E., Mckay, J.K., Mauleon, R., Stephens, J., McNally, K.L., Bush, D.R., Leung, H. \& Leach, J.E. 2011. Genetic variation in biomass traits among 20 diverse rice varieties. Plant Physiology 155: 157-168.

Jie,Z., Yuncong, Y., Streeter, J.G. \& Ferree, D.C. 2013. Influence of soil drought stress on photosynthesis, carbohydrates and the nitrogen and phosphorus absorb in different section of leaves and stem of Fugi/M. 9EML, a young apple seedling. African Journal of Biotechnology 9: 5320-5325.

Juenger, T.E. 2013. Natural variation and genetic constraints on drought tolerance. Current Opinion in Plant Biology 16: 274-281

Kilic, H. \& Yağbasanlar, T. 2010. The effect of drought stress on grain yield, yield components and some quality traits of durum wheat (Triticum turgidum ssp. durum) cultivars. Notulae Botanicae Horti Agrobotanici 38: 164-170.

Lawson, T. \& Blatt, M.R. 2014. Stomatal size, speed, and responsiveness impact on photosynthesis and water use efficiency. Plant Physiology 164: 1556-1570.

Lawson, T., Kramer, D.M. \& Raines, C.A. 2012. Improving yield by exploiting mechanisms underlying natural variation of photosynthesis. Current Opinion in Biotechnology 23: 215-220.

Lawson, T., von Caemmerer, S. \& Baroli, I. 2011. Photosynthesis and stomatal behaviour. Progress Botany 72: 265-304.

Leilah, A. \& Al-Khateeb, S. 2005. Statistical analysis of wheat yield under drought conditions. Journal of Arid Environment 61: 483-496

Nazco, R., Villegas, D., Ammar, K., Peña, R.J., Moragues, M. \& Royo, C. 2012. Can Mediterranean durum wheat landraces contribute to improved grain quality attributes in modern cultivars? Euphytica 185: 1-17.
Nouri-Ganbalani, A., Nouri-Ganbalani, G. \& Hassanpanah, D. 2009. Effects of drought stress condition on the yield and yield components of advanced wheat genotypes in Ardabil. Iranian Journal of Food Agricultural and Environment 7: 228-234.

Ozturk, A. \& Aydin, F. 2004. Effect of water stress at various growth stages on some quality characteristics of winter wheat. Journal of Agronomy and Crop Science 190: 93-99.

Peterson, C., Graybosch, R., Baenziger, P. \& Grombacher, A. 1992. Genotype and environment effects on quality characteristics of hard red winter wheat. Crop Science 32: 98-103.

Pinheiro, C. \& Chaves, M. 2011. Photosynthesis and drought: Can we make metabolic connections from available data? Journal of Experimental Botany 62: 869-882.

Pradhan, G.P., Prasad, P.V., Fritz, A.K., Kirkham, M.B. \& Gill, B.S. 2012. Effects of drought and high temperature stress on synthetic hexaploid wheat. Functional Plant Biology 39: $190-198$

Raines, C.A. 2011. Increasing photosynthetic carbon assimilation in $\mathrm{C}_{3}$ plants to improve crop yield: Current and future strategies. Plant Physiology 155: 36-42.

Reddy, A.R., Chaitanya, K.V. \& Vivekanandan, M. 2004. Drought-induced responses of photosynthesis and antioxidant metabolism in higher plants. Journal of Plant Physiology 161: 1189-1202.

Rharrabti, Y., Villegas, D., Royo, C., Martos-Núñez, V. \& Del Moral, L.G. 2003. Durum wheat quality in Mediterranean environments: II. Influence of climatic variables and relationships between quality parameters. Field Crops and Research 80: 133-140.

Rybka, K. \& Nita, Z. 2015. Physiological requirements for wheat ideotypes in response to drought threat. Acta Plant Physiology 37: 1-13.

Saint-Pierre, C., Peterson, C., Ross, A., Ohm, J., Verhoeven, M., Larson, M. \& Hoefer, B. 2008. Winter wheat genotypes under different levels of nitrogen and water stress: Changes in grain protein composition. Journal of Cereal Science 47: 407-416.

Shangguan, Z., Shao, M., Ren, S., Zhang, L. \& Xue, Q. 2004. Effect of nitrogen on root and shoot relations and gas exchange in winter wheat. Botanical Bulletin Academia Sinica 45: 49-54.

Shewry, P.R., Piironen, V., Lampi, A.M., Edelmann, M., Kariluoto, S., Nurmi, T., Fernandez-Orozco, R., Ravel, C., Charmet, G. \& Andersson, A.A. 2010. The health grain wheat diversity screen: Effects of genotype and environment on phytochemicals and dietary fiber components. Journal of Agriculture and Food Chemistry 58: 9291-9298.

Shukla, N., Awasthi, R., Rawat, L. \& Kumar, J. 2015. Seed biopriming with drought tolerant isolates of Trichoderma harzianum promote growth and drought tolerance in Triticum aestivum. Annual of Applied Biology 166: 171-182.

Steel, R., Torrie, J. \& Dickey, D. 1997. Principles and Procedures of Statistics: A Biometric Approach. $3^{\text {rd }}$ ed. USA: McGraw Hill Companies Inc.

Vandoorne, B., Mathieu, A.S., van Den Ende, W., Vergauwen, R., Périlleux, C., Javaux, M. \& Lutts, S. 2012. Water stress drastically reduces root growth and inulin yield in Cichorium intybus (var. sativum) independently of photosynthesis. Journal of Experimental Botany 63: 4359-4373. 
Tariq Shahzad, Muhammad Mansoor Javaid*, Hasnain Waheed \& Tasawer Abbas

Department of Agronomy

University College of Agriculture

University of Sargodha, Sargodha

Pakistan

Muhammad Ashraf

Pakistan Science Foundation

Islamabad

Pakistan

\section{Feng-Min Li}

School of Life Sciences

State Key Laboratory of Grassland Agro-ecosystems

Lanzhou University, Lanzhou 730000

China
Abdul Sattar

College of Agriculture

BZU, Bahadur Campus Layyah

Pakistan

*Corresponding author; email: mmansoorjavaid@gmail.com

Received: 26 February 2018

Accepted: 4 July 2018 